\title{
REVIEW
}

\section{Opportunities and barriers to establishing a cell therapy programme in South Africa}

\author{
Carlo Stephan Jackson and Michael S Pepper
}

\begin{abstract}
The establishment of a cell therapy programme in South Africa has the potential to contribute to the alleviation of the country's high disease burden and also to contribute to economic growth. South Africa has various positive attributes that favour the establishment of such a high-profile venture; however, there are also significant obstacles which need to be overcome. We discuss the positive and negative features of the current health biotechnology sector. The positive factors include a strong market pull and a highly innovative scientific and medical community, while the most problematic features include the lack of human resources and education and limited funding. The South African Government has undertaken to strengthen the biotechnology sector in general, but a focus on cell therapy is lacking. The next important step would be to provide financial, legal/ethical and other support for groups that are active and productive in this field through the development of a local cell therapy programme.
\end{abstract}

\section{Introduction}

South Africa, based on the World Economic Forum 2011-2012 Global Competitiveness Index evaluation [1], is ranked 50th out of 142 countries and 66th with respect to gross domestic product per capita (US\$7,158). When one breaks this down into individual components, however, South Africa's ranking drops to 131 in the health sector and to 111 regarding the availability of scientists and engineers (Table 1) [1]. It is apparent that South Africa as a country faces significant challenges in the areas of healthcare and scientific capacity. This review focuses on how the healthcare needs of the country could be addressed from a biotechnology perspective, with particular emphasis on cell-based therapy that includes, but is not limited to, stem cells.

Cell-based therapy has been used successfully for several decades in the treatment of an ever-expanding number of haematological and other disorders [2]. This therapy includes the use of human cells, tissues, or cellular and tissue-based products in clinical research/practice [3]. Patients in developing countries have limited access to cell therapy as a therapeutic option. The first priority in developing countries is to ensure that basic medical services are established and maintained [4]; the

\footnotetext{
* Correspondence: michael.pepper@up.ac.za

Department of Immunology, Faculty of Health Sciences, University of Pretoria, P.O. Box 2034, Pretoria 0001, South Africa
}

need for specialised forms of treatment such as cellbased therapies is therefore questioned [5]. This is exemplified in South Africa by the resources required to manage infectious diseases including HIV/AIDS and tuberculosis [6], which draw resources away from specialised treatments [7] as they require prolonged and costly patient care. South Africa also has a high prevalence of noncommunicable diseases including cardiovascular diseases and diabetes [8]. By providing cost-effective lifelong cures for chronic diseases (communicable and noncommunicable), cell therapy could reduce the dual disease burden and free up resources that are currently used for chronic patient care [9]. Economic growth could also be stimulated by a cell therapy programme, as has been the case in industrially advanced countries where this is an important incomegenerating component of the health biotechnology sector [10]. Cell therapy is a high-risk venture and is still in its infancy in South Africa [11]. Identifying whether the current situation in South Africa is suitable for the development of a cell therapy programme is therefore critical.

\section{Opportunities}

\section{A strong market pull}

Although South Africa is advanced in stem cell technologies compared with other African countries [12], the availability of stem cell therapies is still limited. No 
Table 1 World economic forum global competitiveness index estimates for 2011 to 2012

\begin{tabular}{llc}
\hline Subindex & Factor & Rank (out of 142) \\
\hline & Overall ranking & 50 \\
& Basic requirements & 85 \\
& Health and primary education & 131 \\
& Business impact of HIV/AIDS & 132 \\
& Tuberculosis incidence & 141 \\
& HIV prevalence & 139 \\
& Business impact of tuberculosis & 135 \\
& Life expectancy & 130 \\
& Infant mortality & 111 \\
Business impact of malaria & 103 \\
& Malaria incidence & 90 \\
& Innovation and sophistication factors & 39 \\
\hline
\end{tabular}

Data extracted from the World Economic Forum Global Competitiveness Report 2011-2012 [1].

public cord blood bank is active in South Africa although there are two private banks; the bone marrow registry is also demographically misrepresented [13], which provides minimal access and benefit to the majority of the country's population. Haematologists and medical centres that provide stem cell therapies are mainly situated in Gauteng and the Western Cape and are only available from private institutions [14]. There is a strong appeal to make the available stem cell therapies more readily accessible for the currently unmet clinical needs and to develop novel therapies for diseases that burden South Africa.

Despite the fact that a significant proportion of the national budget is allocated to the management of HIV/ AIDS and tuberculosis, their impact on mortality and morbidity in South Africa remains high. The group most affected by these diseases is the economically active sector of the population [15]. Although infectious diseases are currently the most important contributor to South Africa's heavy burden of disease [16], the World Health Organization Global Burden of Diseases Report of 2004 predicts that the relative contribution of infectious diseases in low and middle income countries will drop as we approach 2030 and that the contribution of cardiovascular and other noncommunicable diseases will increase [16]. On the basis of the current market needs in South Africa and these predicted changes, cell-based therapy will need to address infectious diseases as a short-term priority, and lifestyle diseases as a long-term priority. The specific fields of future interest for South Africa include: haematopoietic stem cell transplantation as a second-line treatment for leukaemia and other haematological malignancies [17], haematopoietic transplantation of engineered autologous cells to provide resistance to HIV/AIDS [18], mesenchymal stem cell transplantation for cardiovascular regeneration [19] and the treatment of diabetes [20]. The scope of the disease burden is large and a well-developed strategic plan is therefore needed.

\section{Innovative capacity}

For a cell therapy programme to address these needs, a significant amount of innovation is required. Innovation is not just the discovery of a novel solution to a problem through the successful development of a product or service, but if an innovation is to be dynamic it needs to be driven from several perspectives. These include institutions that facilitate the creation, dissemination and use of novel and economically useful knowledge [21,22] (Figure 1). Research and educational institutions need




to provide optimal support for health-related research, and long-term investment from stakeholders is essential. This needs to be combined with innovative firms that develop new health products or innovative processes that integrate various types of knowledge.

Governments are responsible for supporting health biotechnology by setting up institutions, developing policies and providing legal-regulatory frameworks such as those dealing with intellectual property [21]. South Africa has a Global Competitiveness Index ranking of 46 out of 142 for innovation, with 'government's procurement of advanced technological products' being a major disadvantage [1]. Inter-institutional/departmental collaboration and the understanding and fulfilment of each institution's task in serving a common purpose is a challenge that needs to be met [22]. The recognition of this shortcoming provides an opportunity for the procurement of future advanced technological products, including cell-based therapies.

\section{Recognition of cell therapy's potential}

Cell therapy is on the brink of expanding rapidly as potential therapies, once validated through clinical trials, become available in the clinic. This is evident from the large number of investigations that use stem cells of various types in clinical trials involving a wide range of disorders (Figure 2) [23]. For example, certain autologous cell products are in late clinical trials or are already in clinical use internationally [2], including adiposederived stem cells used for reconstructive breast surgery [24], chondrocytes and mesenchymal stem cells for cartilage repair [25,26], haematopoietic stem cell transplants as the standard second-line treatment for lymphoma [17], keratinocytes and mesenchymal stem cells used for burns wounds [27], satellite cells for skeletal muscle regeneration [28], and bone marrow stem cells applied to denuded donated trachea for airway replacement [29]. It is important for South Africa to strategically position itself to benefit from future therapies

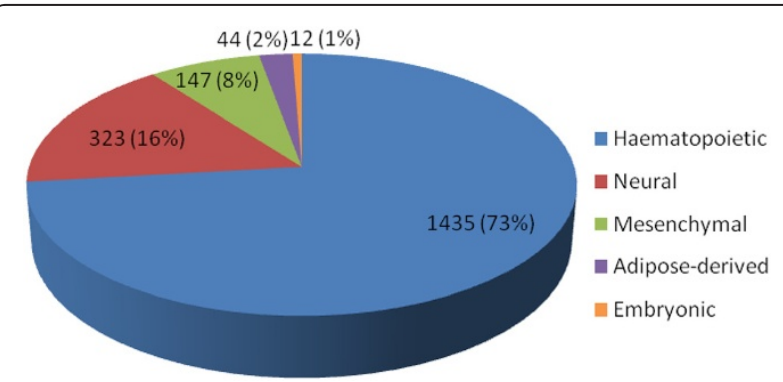

Figure 2 Clinical trials currently underway using stem cells. The numbers of open clinical trials currently underway in which haematopoietic, neural, mesenchymal, adipose-derived, and embryonic stem cells are being used [23]. MSC, mesenchymal stem cell. as they become available. An accredited clean room facility is an important component of a cell therapy programme, and is used for the isolation, expansion and manipulation of stem cells. A cell therapy programme should also include entities involved in the donation, procurement, testing, preservation, storage and distribution of human tissues and cells [30]. The programme will be able to coordinate the translation of stem cell research into cell-based medicinal products for patientenrolled clinical trials and therapies.

The need for a public cord blood bank, which will provide cord blood units to individuals of all ethnic groups in South Africa, is well recognised and is being investigated [31]. Private umbilical cord blood stem cell bank services exist in South Africa, but are controversial due to the negligible recall rate of stored samples that occurs only in very rare cases when the donor or, more often, direct family needs the cells [32]. On the contrary, a public bank is universally accepted and would assure availability of stem cells to any histocompatible individual in the population or abroad [33].

\section{Weaknesses}

\section{Lack of human resources}

Human capital is an important catalytic ingredient for innovation [34] and for the provision of healthcare services [35]. Specialists are necessary to drive the knowledge economy, and tend to move easily between countries due to the great global demand [34]. The highest rates of economic growth and the fastest developments in science and technology occur in countries with the greatest intellectual resources [36].

South Africa loses 40,000 mostly skilled people per annum to international countries, and gains 11,000 mostly unskilled people per year from poorer African countries [37]. South Africa also faces major healthcare problems, including an inequitable distribution and a significant attrition of trained health personnel. A common phenomenon is that skilled health personnel migrate to richer countries and South Africa has not been excluded from this brain drain in the past [37], losing an estimated 3,600 health personnel per annum. As a result, the country is forced to recruit expensive foreign expertise or to accept poorly trained workers from poorer countries [35,38-40]. The lack of skilled health personnel - for example, clinicians (haematologists and oncologists), skilled scientists and laboratory personnel - could affect the successful establishment and maintenance of a cell therapy programme. There are currently about 25 clinical haematologists in South Africa, most of whom are in the private sector. This is equivalent to a ratio of one haematologist per 2 million people. In a country such as the United Kingdom, the ratio is 13.2 per 1 million (R Pool, communication with authors, 2011). 
Even though South Africa has high-quality scientific research institutions [1], the inability to retain expertise for the development of novel technologies, including cell therapy, is the first and perhaps the most important barrier to establishing cell therapy as a discipline in South Africa. It is therefore necessary to provide conditions and incentives for skilled personnel that will encourage them to remain and work in the country [41]. South Africa has implemented a policy that aims to recruit highly qualified professionals in the healthcare sector to overcome these shortcomings [42].

\section{Barriers affecting successful innovation}

An often-mentioned weakness in the innovation/commercialisation chain is the so-called 'innovation chasm' or the 'valley of death'. This refers to the inability of academic research to reach the market as products and services. The National Biotechnology Strategy, which was adopted in 2001, has the aim of inducing an entrepreneurial culture and innovation. This will soon be replaced by a new Bio-economy Strategy, which has built on the experience of the past 10 years [43]. In this time, the National Department of Science and Technology has put into place several instruments to bridge the innovation chasm, the most recent of which are the Technology Innovation Agency and the National Intellectual Property Management Office [44].

In terms of tangible outputs such as biotechnology firms, employment, patents and commercialisation revenues, however, a limited amount of progress has been made over the past decade [45]. One of the reasons for this lack of growth may be the lack of increase in the number of projects entering the innovation pipeline, which for all intents and purposes is empty. This might in part be attributed to higher education institutions and funding agencies that do not implement the guidelines of the National Biotechnology Strategy [45]. The government implemented the new Intellectual Property Regulations from Publicly Funded Research and Development Act in 2010 to promote a commercial outflow from research projects [46] and to drive a better return on publically funded research investment [44]. Although there has been criticism that the Act could negatively affect academia, intra-firm research alliances and international research collaboration [47], it is too early to determine whether this is the case.

\section{Threats}

\section{Limited funding}

South African companies have to compete in the international arena and need to develop new products with substantially less capital [48]. Government expenditure on research and development was R21 billion according to the 2008/2009 research and development survey [49] and, although few in number, funding bodies that fund biotechnology companies do exist, including the Industrial Development Corporation and the Technology Innovation Agency [50]. Despite their best intentions, they still leave a major funding gap [51], which in some cases can be bridged by venture capital. The capital available from venture capital firms for biotechnology is limited, however, but interest in the field is emerging. Bioventures (Northlands, South Africa) has successfully supported several biotechnology projects in South Africa [48]. At this stage, local funding is insufficient for the process of product development and foreign funds are needed. The latter will in part depend on the global perception of South Africa's biotechnology capacity.

\section{Ethics and education}

Aside from technical, political and financial challenges, cell therapy does provoke strong ethical and cultural concerns, due in part to ignorance and a lack of education [33]. The South African bone marrow registry contains more than 65,000 entries [52], which is largely represented by white South Africans [13]. This is of concern as the black South African population is largely underrepresented and is therefore unable to benefit fully from the therapeutic benefit that bone marrow transplantation can provide [53]. This imbalance might in part be historical but is also the result of a lack of education regarding donation and the advantages thereof. Many people in South Africa have also attached cultural and religious beliefs and norms to various body parts, and are reluctant to donate or receive stem cells [54]. This should be taken into account when setting up a cell therapy programme, since it might influence public support and therefore the market.

Obtaining and maintaining an adequate number of cord blood samples for a public bank that is representative of the total population could be challenging. The Public Understanding of Biotechnology programme was created to inform the public of biotechnology opportunities in South Africa, and also to inform people about biotechnology products that might affect them [55]. News and scientific articles have given people false hope and understanding of current stem cell therapies, and as a result desperate patients are enticed to spend large sums of money on unproven stem cell treatments [56]. South Africa has not been spared in this respect, and needs to prevent these exploitative practices before they hamper local public perception and funding opportunities [57]. There is thus an urgent need for a national information centre that can provide information concerning public understanding of the present and future applications of stem cells. 


\section{Inadequate regulatory environment}

A major concern is that the cell therapy environment is in part regulated by legislation that is incomplete, redundant and, in some cases, scientifically flawed. The scientific landscape at the time of the drafting the legislation did not require carefully balanced rules and guidelines for complex and controversial issues regarding human stem cells [58]. Thus, although some aspects of cell therapy appear to be adequately regulated [59], the absence of stem cell regulations in other areas and the inability to enforce existing legislation means that patients do not enjoy protection and are exposed to untested and unsound treatments [60].

Although recently enacted, an urgent revision of the National Health Act is required, particularly as far as cell-based therapies are concerned [60]. Several physicians are already practicing cell therapy in South Africa, and there is a need for these practices to be regulated. The immediate establishment of a national regulatory body is essential for the protection of patients and guidance of the development of cell therapy in the country. One of the body's main roles would be to provide best practice guidelines and training for physicians. These guidelines could be drafted on the basis of international best practice standards. The body could thus promote access to cell therapy, while at the same time protecting patients from bogus therapies [61].

\section{Market barrier}

Will private individuals or the government be able to pay for the cost of cell therapy? The uptake of cell therapy will depend on several factors, which include cost, public perception and the regulatory environment. Treatments will perhaps initially not be paid for by the state or covered by medical aids, and patients will have to pay out of pocket. Cell therapy will therefore probably initially not be accessible to everyone, but will become more affordable over time. The decision of medical aids to cover a new treatment is based on the clinical effectiveness and safety of the treatment. In the case of higher cost treatments, financial cost-sharing mechanisms would have to be formulated between the insurance company and the company providing the service [62]. The main cell therapy market could therefore initially be the private sector [63]. The National Department of Health is struggling to provide basic care with its allocated budget, and, at least initially, would simply not authorise the payment of specialised treatments of this nature [63]. However, a convincing motive to fund cell therapy is the possibility of obtaining a one-off treatment, with a significantly lower overall cost when compared with conventional long-term patient care [7]. HIV/AIDS is the main contributor to the disease burden and therefore constitutes the main domestic market, and cell therapy treatments for this disease could establish a good market-related foothold in South Africa [18].

\section{Strengths}

\section{Public-sector initiatives}

Although the local biotechnology industry is small by international standards, it has significant potential. A number of structures and interventions aimed at strengthening the biotechnology sector have been implemented, including, as mentioned previously, the Technology Innovation Agency and the National Intellectual Property Management Office. Incubators have also been created to facilitate the innovation process by supporting the development of entrepreneurial companies with both technology and business incubation.

The Innovation Hub, Africa's first internationally accredited Science Park, was created with the goal of assisting at least 20 biotechnology companies with the commercialisation of life sciences research, products and services [64]. The International Centre for Genetic Engineering and Biotechnology, which is dedicated to biotechnology, was opened in Cape Town in 2007 [65]. The centre is an intergovernmental centre of excellence for research and training in biotechnology and genetic engineering, which focuses on the needs of the developing world [66]. Hosting the facility has established the country as a preferred destination for science and technology initiatives, and has helped to attract highly skilled scientists to Cape Town [67]. Health-specific biotechnology innovations are also harnessed to address public health problems, such as the development of vaccines through the South African AIDS Vaccine Initiative (Cape Town, South Africa) [68]. In the health biotechnology sector, stem cell research, banking and therapy are already taking place in South Africa. Two private cord blood stem cell banks exist, namely Cryo-Clinic and Netcells Biosciences. The acute need for a public stem cell bank has been recognised and a feasibility study is underway even though it demands significant capital investment and it is not a health priority given the heavy burden of communicable and noncommunicable diseases [69].

Although the South African Government has identified the biotechnology sector as an important contributor to economic growth and the well-being of all South Africans, no national initiative has yet been undertaken to develop cell therapy in the country. A carefully structured strategy must be put in place to overcome the identified barriers. According to the UK stem cell initiative report, this type of venture needs to be a government initiative in order to be successful [10]. A cell therapy initiative is recommended to be comprised of higher education institutions, research councils, private funding bodies, and a specialised research ethics committee. Further responsibilities include the establishment 
of public-private partnerships and coordinating bodies to support research, and the development of a programme of public dialogue [10]. If such a strategy can be implemented it will support the potential ability of South Africa to establish a successful cell therapy programme and to attract foreign investment.

\section{Conclusion}

Cell therapy could provide South African patients with a suitable alternative to conventional treatments and is likely to have a positive impact on the country's economy. This is a high-profile venture that requires innovation and careful planning and implementation. It is not practical to consider all possible cell-based therapies in the light of the regulatory, staffing and resource limitations.

South Africa, as a developing country, has many strengths but also has barriers that need to be overcome if a thriving cell therapy industry is to be developed. The government has launched several major strategic initiatives to remedy the shortcomings in the biotechnology sector, but lacks a focus on cell therapy. We recommend the establishment of a national cell therapy programme that would be dedicated to the coordination of development of stem cell research and therapy. This group should be responsible for making the available treatments more accessible in the short term, mainly by establishing clinical haematologic facilities in collaboration with universities and to thereby train clinical haematologists. The group could assist the bone marrow registry to improve the demographic representation of the registrars. The national programme should regulate cell therapy treatments and clinical trials in collaboration with partners in the international stem cell arena, and should also serve as a connection point to provide education and information to the public regarding stem cell treatments. The national cell therapy programme's longterm strategy should be to facilitate the development of locally inspired stem cell solutions.

Setting up a cell therapy programme in South Africa at this time is important, but will require strong leadership and the coordinated efforts of role-players in several sectors to initiate clinical translation of potential to actual treatments.

\section{Competing interests}

The authors declare that they have no competing interests.

\section{Acknowledgements}

The authors are grateful for the financial support received from the Medical Research Council and Deutscher Akademischer Austausch Dienst-National Research Foundation.

\section{References}

1. The global competitiveness report. [http://www.weforum.org/reports/ global-competitiveness-report-2011-2012]

2. Medical Research Council of the United Kingdom: A Strategy for UK Regenerative Medicine. London; 2012.

3. Human Cells, Tissues, and Cellular and Tissue-Based Products Regulations. $21 \mathrm{C}$. F.R., Part 1271. Washington: U.S. Government printing office; 2012.

4. Department of Health: White Paper for the Transformation of the Health System in South Africa. Pretoria; 1997.

5. Department of Health: Strategic Priorities for the National Health System 2004-2009. Pretoria; 2004

6. Bell C, Devarajan S, Gersbach H: The Long-run Economic Costs of AIDS: Theory and an Application to South Africa. Paris: UNESCO; 2003:1-118.

7. Bollinger $L$, Stover J: The economic impact of AIDS in South Africa. [http:// www.policyproject.com/pubs/SElmpact/southafr.pdf]

8. World Health Organization: Global Status Report on Noncommunicable Diseases 2010. Geneva: WHO; 2011:1-176.

9. Chhabra P, Mirmira RG, Brayman KL: Regenerative medicine and tissue engineering: contribution of stem cells in organ transplantation. Regen Med 2009, 14:46-50

10. UK Stem Cell Initiative: Report \& Recommendations of the UK Stem Cell Initiative. London: Department of Health; 2005:1-122.

11. Price Waterhouse Coopers: Biotech Reinvented: Where Do You Go From Here? Sinninghill; 2010 .

12. Current state of stem cell research and its application in South Africa. [http://embrybros.wordpress.com/2011/04/06/current-state-of-stem-cellresearch-and-its-application-in-south-africa/]

13. South African bone marrow registry annual general meeting. [http:// www.sabmr.co.za/agm2008report.pdf]

14. Netcells: stem cell therapy. [http://www.netcells.co.za/therapy-introduction. php]

15. Erasmus G, Nkau DJ: Towards a 10-year Review of the Population Policy Implementation in South Africa (1998-2008). Pretoria: Government Communication and Information System; 2009:1-66.

16. World Health Organization: The Global Burden of Disease. Geneva: WHO; 2004:1-160.

17. Gunnellini M, Emili R, Coaccioli S, Liberati AM: The role of autologous stem cell transplantation in the treatment of diffuse large B-cell lymphoma. Advin Hematol 2012, 2012:1-10.

18. H-peter K, Jerome KR, Deeks SG, Mccune JM: Review hematopoietic-stemcell-based gene therapy for HIV disease. Stem Cell 2012, 10:137-147.

19. Elnakish MT, Hassan F, Dakhlallah D, Marsh CB, Alhaider IA, Khan M: Mesenchymal stem cells for cardiac regeneration: translation to bedside reality. Stem Cells Int 2012, 2012:1-14.

20. Pileggi A: Mesenchymal stem cells for the treatment of diabetes. Diabetes 2012, 61:1355-1356.

21. Nelson RR, Nelson K: Technology, institutions, and innovation systems. Res Policy 2002, 31:265-272

22. Thorsteinsdóttir H, Quach U, Martin DK, Daar AS, Singer PA: Introduction: promoting global health through biotechnology. Nat Biotechnol 2004, 22:3-7.

23. ClinicalTrials.gov. [www.clinicaltrials.gov]

24. BlueCross BlueShield of North Carolina: Corporate Medical Policy Autologous Fat Grafting to the Breast 'Notification'. Durham; 2012.

25. Melero-Martin JM, Al-Rubeai M: In vitro expansion of chondrocytes. In Topics in Tissue Engineering, Volume 3. Edited by Ashammakhi N, Reis R, Chielline E. Oulu, Finland: Biomaterials and Tissue Engineering Group; 2007:1-37.

26. Stuart M: Cartilage repair: what's the right combination? Start-up 2009, 14:1-9.

27. Arno A, Smith AH, Blit PH, Shehab MA, Gauglitz GG, Jeschke MG: Stem cell therapy: a new treatment for burns? Pharmaceuticals 2011, 4:1355-1380.

28. Tedesco FS, Dellavalle A, Diaz-manera J, Messina G, Cossu G: Review series repairing skeletal muscle: regenerative potential of skeletal muscle stem cells. J Clin Investig 2010, 120:1-9.

29. Elliott MJ, Coppi PD, Speggiorin S, Roebuck D, Butler CR, Samuel E, Crowley C, Mclaren C, Fierens A, Vondrys D, Cochrane L, Jephson C, Janes S, Beaumont NJ, Cogan T, Bader A, Seifalian AM, Hsuan JJ, Lowdell MW, Birchall MA: Stem-cell-based, tissue engineered tracheal replacement in a child: a 2-year follow-up study. Lancet 2012, 380:994-1000. 
30. European Commission: Establishment of Institutional Control on the Safety and Quality of Human Tissues and Cells Used for Transplantation Development of a National Centre for Tissue and Cell Banking. Warsaw; 2004

31. Crookes R, Toit E, Oudshoorn M: A public cord blood bank for South Africa? [www.cips.up.ac.za]

32. Chima SC, Mamdoo F: Ethical and regulatory issues surrounding umbilical cord blood banking in South Africa. S Afr J Bioethics Law 2011, 4:79-84.

33. Pepper MS: Letter: regaining perspective on stem cells. $S$ Afr Fam Pract 2010, 52:2010-2010.

34. Kahn M, Blankley W, Rasigan M, Pogue T, Vijay R, Gabriel C, du Marissa T: Flight of the Flamingos: A Study on the Mobility of R\&D Workers. Cape Town: HSRC Publishers; 2004:1-74.

35. Department of Labor South Africa: The Shortage of Medical Doctors in South Africa. Pretoria; 2007

36. Tackling the roots of the brain drain. [http://www.scidev.net/]

37. Rogerson C: Medical Recruits: The Temptation of South African Health Care Professionals. 45th edition. Cape Town: South African Migration Project 2007:1-52.

38. Government wakes up to flight of health workers. [http://www.irinnews org/printreport.aspx? reportid=39849]

39. Health personnel in Southern Africa: confronting maldistribution and brain drain. [http://ww.medact.org/content/health/documents/brain_drain/ Padarath\%20et\%20al.\%20-\%20Medact-HST-Equient.pdf]

40. Bohlman HR: The macroeconomic impact of skilled emigration from South Africa: a CGE analysis. [http://www.econrsa.org/publications/ working-papers/macroeconomic-impact-skilled-emigration-south-africa-cgeanalysis]

41. Accelerated and Shared Growth Initiative for South Africa: Accelerated and shared growth initiative for South Africa annual report 2007. [http:// www.info.gov.za/view/DownloadFileAction?id=80162

42. Department of Health: Employment of Foreign Health Professionals in the South African Health Sector. Pretoria; 2010.

43. Gastrow M: Great expectations: the state of biotechnology research and development in South Africa. Journal of Biotechnology 2008, 7:342-348.

44. Moore R: Perceived pros and cons of the intellectual property rights from Publicly Financed Research and Development Act. [http://www. freemarketfoundation.com/publications/rory-moore-perceived-pros-andcons]

45. Organisation for Economic Co-operation and Development: Reviews of innovation policy. South Africa: OECD; 2007.

46. South African Government: Intellectual property rights Act, 2008. Government Gazette 2008, 522:1-20. Green Gazette SA (Pty) Ltd: Randburg.

47. Staphorst $L$ : The impact of intellectual property rights from publicly financed research and development on governance mode decisions for research alliances. In PhD thesis. University of Pretoria, Gordon Institute of Business Science; 2010

48. Sherwin $\mathrm{H}$ : The challenges of starting up a biotech company in South Africa. [http://www.biosa.org.za/pdfs/heathersherwin.pdf]

49. Human Sciences Research Council: 2008/2009 National Survey of Research \& Experimental Development. Cape Town; 2011.

50. Technology Innovation Agency: Annual Report 2011/2012. Pretoria; 2012.

51. Al-bader S, Frew SE, Essajee I, Liu VY, Daar AS, Singer PA: Small but tenacious: South Africa's health biotech sector. Nat Biotechnol 2009, 27:427-445

52. du Toit ED, Schlophoff T, Borrill V: The South African bone marrow registry - role in providing unrelated donors for allogeneic stem cell transplantation. Contin Med Educ 2012, 30:293-294.

53. American $\mathrm{A}$ : Visible felt leadership: building a truly sustainable safety culture. A Magazine 2012, 10:1-34

54. Davis C: The influence of religion on organ donation and transplantation among the black Caribbean and black African population - a pilot study in the United Kingdom. Ethnicity Dis 2006, 16:281-285.

55. Department of Science and Technology: National Biotechnology Audit. Pretoria; 2007.

56. Pepper MS: Cell-based therapy - navigating troubled waters. Stem Cells 2010, 100:1-2

57. Mahomed S, Slabbert MN: Stem cell tourism in South Africa: the legal position. S Afr Jof Bioethics Law 2012, 5:69-73.

58. Pepper MS: The stem cell regulatory environment in South Africa - cause for concern. PLoS Med 2009, 99:505-507.
59. Jordaan DW: Regulatory crackdown on stem cell therapy: what would the position be in South Africa? S Afr Med J 2012, 102:219-220.

60. Pepper MS: Partial relief from the regulatory vacuum involving human tissues through enactment of chapter 8 of the National Health Act and regulations thereto. S Afr Med J 2012, 102:1-2

61. Ledford H: FDA challenges stem-cell clinic. Nat News 2010, 466:909.

62. Fulton BD, Felton MC, Pareja C, Potischman A, Scheffler RM: Coverage, costcontrol mechanisms, and financial risk-sharing alternatives of high-cost health care technologies. Berkeley: California Institute for Regenerative Medicine; 2009:1-36.

63. Lehohla P: In-depth analysis of the general household survey data. Stat $S$ Afr 2009, 2:1-50.

64. Research and Information Department: The Relevance of the Biotechnology Industry to South Africa's Healthcare Sector. Sandton; 2007

65. Department of Science and Technology: Major International Biotechnology Research Laboratory Opens Its Doors in South Africa. Pretoria; 2007.

66. Ripandelli D: An example of international scientific cooperation: the international centre for genetic engineering and biotechnology. [http://international.asm.md/files/cei/241008/DRipandelli241008.pdf]

67. Global Biotech Lab Opens in SA - SouthAfrica.info. [http://www southafrica.info/about/science/icgeb-110907.htm]

68. Motari M, Quach U, Thorsteinsdóttir H, Martin DK, Daar AS, Singer PA: South Africa - blazing a trail for African biotechnology. Nat Biotechnol 2004, 22:37-41

69. Jordaan DW, Woodrow C, Pepper MS: Banning private stem cell banks: a human rights analysis. S Afr J Human Rights 2009, 25:126-151.

\section{doi:10.1186/scrt204}

Cite this article as: Jackson and Pepper: Opportunities and barriers to establishing a cell therapy programme in South Africa. Stem Cell Research \& Therapy 2013 4:54 